\title{
Add-on Pegylated Interferon Alpha-2a Therapy in Chronic Hepatitis B Japanese Patients Treated with Entecavir
}

\author{
Hideyuki Tamai, Yoshiyuki Ida, Naoki Shingaki, Ryo Shimizu, Kazuhiro Fukatsu, \\ Masahiro Itonaga, Takeichi Yoshida, Yoshimasa Maeda, Kosaku Moribata, Takao Maekita, \\ Mikitaka Iguchi, Jun Kato, and Masayuki Kitano
}

\begin{abstract}
Second Department of Internal Medicine, Wakayama Medical University, 811-1 Kimiidera, Wakayama City, Wakayama 641-0012, Japan
\end{abstract}

Correspondence should be addressed to Hideyuki Tamai; tamahide@wakayama-med.ac.jp

Received 23 December 2016; Revised 16 February 2017; Accepted 21 February 2017; Published 11 April 2017

Academic Editor: Yoichi Hiasa

Copyright (C) 2017 Hideyuki Tamai et al. This is an open access article distributed under the Creative Commons Attribution License, which permits unrestricted use, distribution, and reproduction in any medium, provided the original work is properly cited.

\begin{abstract}
Entecavir requires long-term administration. Pegylated interferon (PEG-IFN) therapy leads to significant reduction of hepatitis B surface antigen (HBs Ag) levels. This study aimed to assess the safety and efficacy of adding PEG-IFN- $\alpha$ - 2 a to entecavir toward cessation of entecavir. A total of 23 patients treated with entecavir underwent add-on PEG-IFN- $\alpha$-2a therapy ( $90 \mu \mathrm{g}$ per week) for 48 weeks. Viral response (VR) was defined as more than $50 \%$ reduction of baseline hepatitis B surface antigen (HBs Ag) level at 72 weeks from the start of therapy. Complete response (CR) was defined as the decline of HBs Ag levels $<100 \mathrm{IU} / \mathrm{mL}$. Hepatitis $\mathrm{B}$ e antigen ( $\mathrm{HBe} \mathrm{Ag}$ ) seroconversion rate was $25 \%(2 / 8)$, and VR rate was 52\% (12/23). CR was observed in four patients (17\%). However, CR rate in baseline $\mathrm{HBs} \mathrm{Ag}$ level $<2000 \mathrm{IU} / \mathrm{mL}$ and $\mathrm{HBe} \mathrm{Ag}$ negative patients was 50\% (4/8). Univariate analysis showed that the percentage of HBs Ag level reduction at week 12 was significantly associated with VR. The area under the curve value was 0.848. Adding PEG-IFN- $\alpha$-2a to entecavir has limited efficacy. The percentage reduction of HBs Ag level at week 12 may be a useful predictor for VR.
\end{abstract}

\section{Introduction}

The current standard treatment for patients with chronic hepatitis $B(\mathrm{HB})$ is pegylated interferon alpha-2a (PEG-IFN$\alpha-2 a)$ or nucleoside analogs (NAs). NAs selectively inhibit viral DNA replication and are extremely safe and effective. In Japan, entecavir has been approved by the national health insurance in 2006. At present, it is the most widely used first-line NA because of its low risk of resistant viruses compared with lamivudine [1]. However, because relapse risk of severe hepatitis after discontinuation is high, long-term administration is needed [2-4]. Furthermore, there are some notable problems associated with long-term administration of entecavir such as increased risk of resistant viruses, safety concerns, teratogenicity, and high medical costs. In contrast, although the antiviral effect of interferon (IFN) is inferior to that of NAs, IFN activates antiviral immunity and can lower hepatitis B surface antigen (HBs Ag) level compared with entecavir [5].
In 2001, Serfaty et al. first reported that sequential therapy with lamivudine and IFN- $\alpha$ can induce a sustained virologic response, including $\mathrm{HBs}$ seroconversion, in patients with chronic hepatitis B not responding to IFN-alpha alone [6]. Chen et al. reported that long-term combination therapy with IFN and NA achieved a high rate of HBs Ag clearance [7]. Notably, Kittner et al. demonstrated that add-on PEG-IFN- $\alpha$-2a induced HBsAg seroconversion in 2 out of 12 patients [8]. In Japanese guidelines, risk assessment of relapse following cessation of NAs has been shown, and NAs may be safely stopped in patients whose HBsAg level decreased to $<1.9 \log$ IU/mL [9]. PEG-IFN therapy leads to notable reduction of HBs Ag levels, whereas the levels did not decrease in patients treated with entecavir alone [10]. Therefore, if a marked reduction of the HBs Ag level appears with additional IFN therapy in patients being treated with entecavir, entecavir may be discontinued safely. To date, there is insufficient evidence of how much HBs Ag level decreases in Japanese patients with chronic hepatitis B and how many 
patients have achieved cessation of entecavir with add-on IFN. Therefore, in this study, we aimed to assess the safety and efficacy of adding PEG-IFN- $\alpha$-2a to entecavir.

\section{Patients and Methods}

2.1. Patients. A total of 23 patients treated with entecavir underwent add-on PEG-IFN- $\alpha$-2a therapy in our hospital between July 2012 and May 2014. Patients were enrolled if all of the following criteria were fulfilled: (1) HBs Ag level $>100 \mathrm{IU} / \mathrm{mL}$; (2) 20 years of age or older; (3) granulocyte count $>1500 / \mathrm{mm}^{3}$; (4) platelet count $>70,000 / \mathrm{mm}^{3}$; and (5) hemoglobin ( $\mathrm{Hb}$ ) levels $>10 \mathrm{~g} / \mathrm{dL}$. The exclusion criteria were (1) hepatic failure or cancer; (2) using shosaikoto (a traditional Chinese medicine); (3) intractable heart disease; and (4) uncontrollable psychoneurotic disorders. All enrolled patients underwent abdominal ultrasonography and contrast computed tomography for diagnosis of liver cirrhosis and hepatocellular carcinoma (HCC) screening within 1 month before the start of therapy. Liver cirrhosis was clinically diagnosed using the morphologic appearance with portal hypertension, such as portosystemic shunt or hypersplenism on imaging or liver histology.

This is a prospective cohort study of add-on PEG-IFN$\alpha$-2a therapy in Japanese patients with chronic hepatitis B treated with entecavir. All study protocols were approved by the ethics committee of our hospital (number 1092). Written informed consent was obtained from all patients included in this study. This study was registered on the University Hospital Medical Information Network (trial ID 8693).

2.2. Treatment Regimens. The standard dose of PEG-IFN- $\alpha$ 2a (Pegasys ${ }^{\circledR}$; Roche, Basel, Switzerland) in Japan was used; $90 \mu$ g PEG-IFN- $\alpha$-2a was administered subcutaneously once a week for 48 weeks [5]. A dose of $0.5 \mathrm{mg}$ entecavir (Baraclude; Bristol-Myers Squibb, New York, USA) was administered daily even after the introduction of add-on PEG-IFN$\alpha$-2a treatment. PEG-IFN- $\alpha$-2a was interrupted based on the following criteria: (1) $\mathrm{Hb}<8.5 \mathrm{~g} / \mathrm{dL}$; (2) granulocyte count < $500 / \mathrm{mm}^{3}$, or the platelet count $<25,000 / \mathrm{mm}^{3}$; and (3) attending physician deeming necessary due to adverse events. The treatment could be restarted if cytopenia improved. If there was no improvement in hematological parameters or adverse events within four weeks, this therapy was discontinued.

2.3. Laboratory Tests. Hepatitis B virus (HBV) genotype was determined using enzyme immunoassay. Hepatitis B e antigen (HBe Ag) level was measured using chemiluminescent immunoassay. HBs Ag levels were measured using the Archect HBs-QT (Abbott Laboratories, Chicago, IL, USA). HBV-DNA was measured using the COBAS TaqMan PCR assay (Roche Diagnostics, Branchburg, NJ, USA). Single nucleotide polymorphism (SNP) of interleukin-28B (IL28B) host genotype (rs8099917) [11] was also evaluated after obtaining written informed consent for genome analysis from each patient. Homozygosity for the major allele (T/T) was defined as IL-28B major type, and heterozygosity (T/G) or homozygosity for the minor allele $(\mathrm{G} / \mathrm{G})$ as IL-28B minor type. In addition to biochemical analyses including serum alanine aminotransferase (ALT), $\gamma$-glutamyl transpeptidase $(\gamma \mathrm{GTP})$, total bilirubin, prothrombin time, and albumin, levels of fibrosis markers (Type IV collagen 7S and hyaluronic acid) and alpha-fetoprotein (AFP) were measured within one month before the start of therapy. During therapy, blood cell counts were performed every week before treatment up to 8 weeks after the start of therapy, and HBs Ag, HBs antibody, $\mathrm{HBe} \mathrm{Ag}, \mathrm{HBe}$ antibody, and HBV-DNA levels and biochemical analyses (liver and renal functional tests) were measured every 4 weeks up to 24 weeks after the end of therapy.

2.4. Assessment of Effectiveness and Safety. The final outcome was evaluated at 24 weeks from the end of add-on PEG-IFN$\alpha$-2a therapy. For the analysis of factors contributing to the $\mathrm{HBs}$ Ag reduction, viral response (VR) was defined as more than 50\% reduction of the baseline HBs Ag level. In Japanese guidelines, $1.9 \log \mathrm{IU} / \mathrm{mL}$ for HBs $\mathrm{Ag}$ is set as the cutoff level at the time of stopping NAs in patients with negative results for $\mathrm{HBe} \mathrm{Ag}$ and $\mathrm{HBV}-\mathrm{DNA}<3.0 \mathrm{log} \mathrm{IU} / \mathrm{mL}$ [9]. Accordingly, complete response (CR) was defined as achievement of HBs Ag level $<100 \mathrm{IU} / \mathrm{mL}$.

Patients were assessed for safety and tolerability during treatment by their attending physician who monitored adverse events and laboratory abnormalities, such as blood cell counts, every week up to week eight. Thereafter, the patients were followed up monthly to 24 weeks after the end of therapy. The incidence and reasons for therapy discontinuation were analyzed.

2.5. Statistical Analysis. Therapeutic effectiveness was determined using an intention-to-treat (ITT) analysis that included patients who did not complete the scheduled course of therapy. Predictive factors for VR were also analyzed using a ITT analysis. Mann-Whitney $U$ test was used to analyze continuous variables. Fisher's exact test or the chi-square test was used to analyze categorical variables. Each optimal cutoff value for continuous variables of VR-predicting factors was decided by the Youden Index method on the basis of the receiver operating characteristics (ROC) curve. The VR predictability of significant contributing factors was evaluated by measuring the area under the curve (AUC). The sensitivity, specificity, positive predictive value (PPV), negative predictive value (NPV), and accuracy for VR were calculated. Values of $p<0.05$ were considered significant. The statistical software used was SPSS version 20.0J for Windows (SPSS, Inc., Tokyo, Japan).

\section{Results}

3.1. Baseline Background Factors. The patients' baseline characteristics are summarized in Table 1.

3.2. Therapeutic Effectiveness. HBe seroconversion was seen in 2 patients (25\%). Although no $\mathrm{HBs} \mathrm{Ag}$ disappearance was seen, CR was observed in 4 patients (17\%), and all of them were $\mathrm{HBe} \mathrm{Ag}$ negative patients. $\mathrm{CR}$ rate in $\mathrm{HBe} \mathrm{Ag}$ negative patients was $27 \%(4 / 15)$. VR rate was $52 \%(12 / 23)$. Comparison of HBs Ag levels between VR and no VR groups 
TABLE 1: Patients' baseline characteristics $(n=23)$.

\begin{tabular}{lc}
\hline Age (years) (range) & $47(30-65)$ \\
Body weight $(\mathrm{kg})$ & $64.5(45.0-110.5)$ \\
Body mass index $\left(\mathrm{kg} / \mathrm{m}^{2}\right)$ & $23.2(17.9-32.3)$ \\
Prior interferon therapy & $7(30 \%)$ \\
History of HCC treatment & $6(26 \%)$ \\
Genotype B/C & $2(9 \%) / 21(91 \%)$ \\
Duration of prior entecavir (days) & $1379(371-2410)$ \\
HBe Ag positive & $8(35 \%)$ \\
HBV-DNA $(\log \mathrm{IU} / \mathrm{mL})$ & $2.1(0-2.4)$ \\
HBs Ag $(\mathrm{IU} / \mathrm{mL})$ & $11(48)$ \\
Liver cirrhosis $(\%)$ & $20(87)$ \\
IL28B (rs8099917) major & $4870(2920-9100)$ \\
White blood cell $\left(/ \mathrm{mm}{ }^{3}\right)$ & $14.8(12.0-16.5)$ \\
Hemoglobin $(\mathrm{g} / \mathrm{dL})$ & $17.8(9.3-28.4)$ \\
Platelets $\left(\times 10^{4} / \mathrm{mm}{ }^{3}\right)$ & $21(10-47)$ \\
ALT $(\mathrm{IU} / \mathrm{L})$ & $24(11-82)$ \\
$\gamma$ GTP $(\mathrm{IU} / \mathrm{L})$ & $2.2(1-6.9)$ \\
Alpha-fetoprotein $(\mathrm{ng} / \mathrm{mL})$ & $3.8(2.5-5.4)$ \\
Type IV collagen $7 \mathrm{~S}(\mathrm{ng} / \mathrm{mL})$ & $48(10-266)$ \\
Hyaluronic acid $(\mathrm{ng} / \mathrm{mL})$ &
\end{tabular}

HCC, hepatocellular carcinoma; HBe Ag, hepatitis B e antigen, HBs Ag, hepatitis B surface antigen; HBV, hepatitis B virus; IL, interleukin; ALT, alanine aminotransferase; $\gamma \mathrm{GTP}, \gamma$-glutamyltransferase.

Values are expressed as medians (range) or numbers of patients (percent).

is shown in Figure 1. Changes of HBs Ag levels of patients with complete response are shown in Figure 2. CR rate in baseline $\mathrm{HBs}$ Ag level $<2000 \mathrm{IU} / \mathrm{mL}$ and HBe Ag negative patients was $50 \%(4 / 8)$.

There were no patients with new-onset hepatocellular carcinoma during the observation period. Entecavir could be discontinued in one patient by seroclearance of HBs Ag after one year from the end of add-on PEG-IFN therapy.

3.3. Contributing Factors for VR and Prediction of VR. Comparisons of pre- and on-treatment factors between the VR and no VR groups are shown in Table 2. ALT level was the only significant pretreatment factor associated with VR. Age, sex, time of previous entecavir therapy, $\mathrm{HBe} \mathrm{Ag}$ positivity, HBV genotype, $\mathrm{HBs}$ Ag level, and interleukin-28B polymorphism were not significant. Among on-treatment factors, the percentage reductions of HBs Ag levels at weeks 12 and 16 were significant contributing factors for VR. AUC values according to significant contributing factors for VR are shown in Table 3. The AUC value of the percentage reduction of $\mathrm{HBs} \mathrm{Ag}$ at week 12 was the highest. The sensitivity, specificity, PPV, NPV, and accuracy for VR are summarized according to significant contributing factors shown in Table 4. Predictability of VR using percentage reduction of $\mathrm{HBs} \mathrm{Ag}$ level at week 12 was equal to that at week 16.

3.4. Safety and Tolerability. The overall adverse events are shown in Table 5. A 38-year-old female discontinued PEGIFN therapy due to arrhythmia at 36 weeks after the start of therapy. She neither was advanced in age nor had cirrhosis.

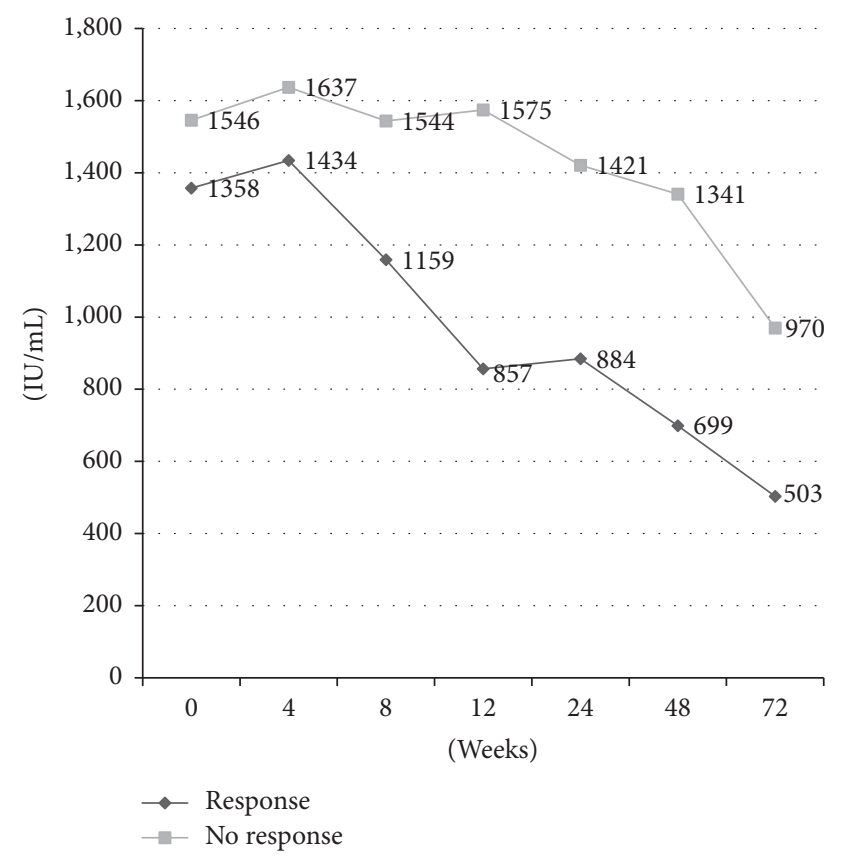

FIgURE 1: Comparison of HBs Ag levels between viral response and no viral response groups. Data were expressed as medians.

Treatment discontinuation rate was $4 \%(1 / 23)$. Treatment interruption rate was $17 \%(4 / 23)$.

\section{Discussion}

This is the first report of add-on PEG-IFN- $\alpha$-2a therapy in Japanese patients treated with entecavir. Liaw et al. reported that a dose of $180 \mu \mathrm{g}$ PEG-IFN- $\alpha$-2a was efficacious and beneficial for patients infected with $\mathrm{HBV}$ genotype $\mathrm{B}$ or $\mathrm{C}$ compared with a dose of $90 \mu \mathrm{g}$ dose [12]. In addition, the dosage of $180 \mu \mathrm{g}$ PEG-IFN- $\alpha$-2a was used in combination with NA in many countries [13-15]. In the present study, however, a dosage of $90 \mu \mathrm{g}$ PEG-IFN- $\alpha$-2a was used because it was recommended by a Japanese clinical trial of PEG-IFN$\alpha$-2a monotherapy for patients with chronic active hepatitis $B$ [5]. Additionally, this dosage was considered to be safer compared with a $180 \mu \mathrm{g}$ dose, which is also the recommended dose for cirrhotic patients infected with hepatitis $\mathrm{C}$ virus in Japan [16]. The discontinuation rate due to adverse effects in the present study was low (4\%). Also, despite the fact that 11 cirrhotic patients were included in the present study, there was no discontinuation in cirrhotic patients. Therefore, this regimen was considered to be safe. As advanced fibrosis is common in older patients with $\mathrm{HBe} \mathrm{Ag}$ negative chronic hepatitis, and NAs are the first-line treatment for cirrhotic patients, the proportion of aged and cirrhotic patients who are receiving long-term entecavir therapy is relatively high compared with that of patients with $\mathrm{HBe} \mathrm{Ag}$ positive chronic hepatitis. Therefore, the lower dosage of $90 \mu \mathrm{g}$ of PEG-IFN$\alpha$-2a for add-on therapy would be a safe and more assessable dose even for aged and/or cirrhotic patients receiving longterm entecavir therapy. 


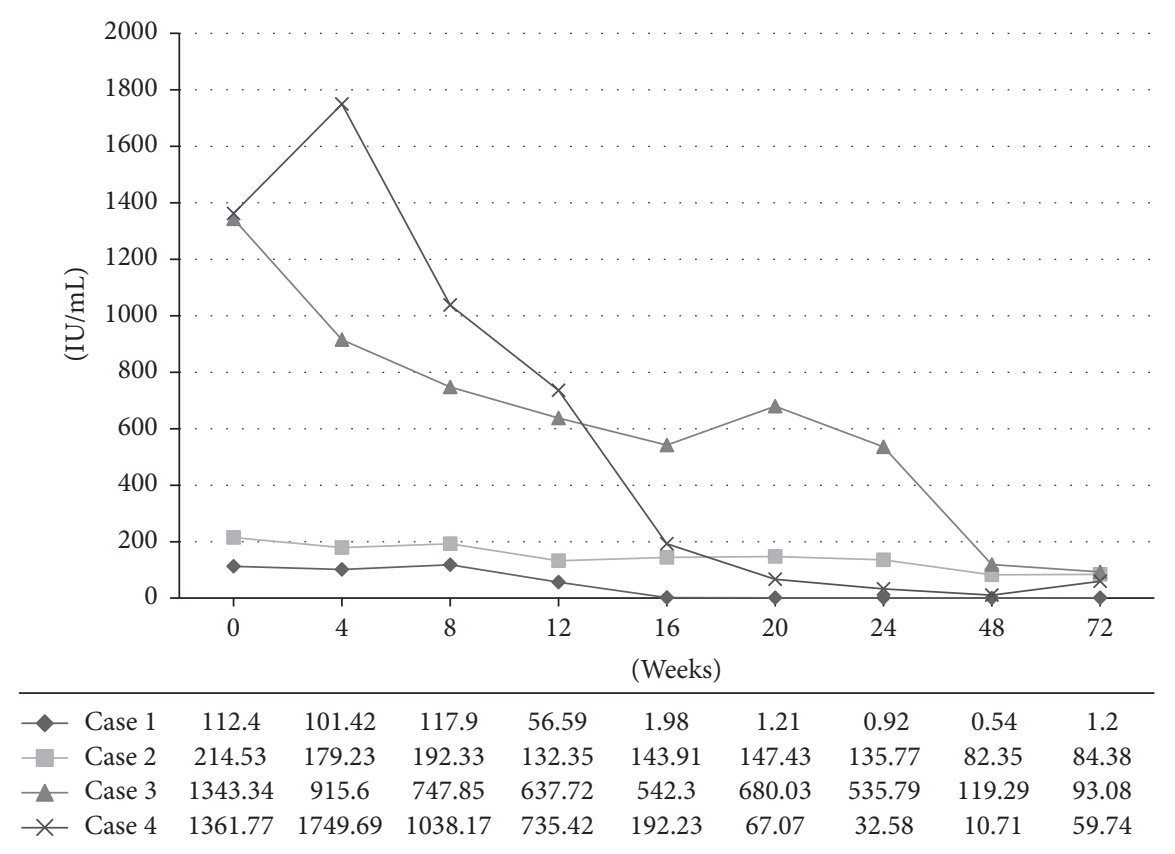

FIgURE 2: Changes of HBs Ag levels of patients with complete response.

The CR rate in the present study was low (17\%), and the disappearance of $\mathrm{HBs} \mathrm{Ag}$ or $\mathrm{HBs}$ seroconversion was not seen. If the aim of add-on PEG-IFN- $\alpha$-2a therapy was to safely discontinue entecavir, this regimen would be considered insufficient. Regarding the efficacy of adding PEGIFN to NA therapy, Ouzan et al. reported that the addition of $180 \mu \mathrm{g}$ of PEG-IFN- $\alpha$-2a for a maximum of 96 weeks based on HBsAg-titer monitoring led to a loss of HBsAg and cessation of NA therapy in six out of ten patients $(60 \%)$, with no relapse [17]. Marcellin et al. reported that the rates of HBs Ag loss were significantly higher in the group treated with tenofovir plus PEG-IFN for 48 weeks than in the group (6.5\%) treated with tenofovir plus PEG-IFN for 16 weeks and tenofovir for 32 weeks (0.5\%) [18]. Therefore, longerterm add-on PEG-IFN- $\alpha$-2a therapy would be needed for the cessation of NA. However, adverse effects are common in high-dose IFN therapy especially in cirrhotic patients and the elderly. Adequate doses of PEG-IFN for long-term treatment should be clarified in the future.

In the present study, HBs Ag levels in most of the patients were decreased in varying degrees during add-on PEG-IFN$\alpha-2 \mathrm{a}$, and the decrease continued even after add-on PEGIFN- $\alpha-2 \mathrm{a}$ therapy. Furthermore, this reducing effect of HBs Ag level gradually appeared 12 weeks after the start of addon PEG-IFN- $\alpha-2$ a. This phenomenon is significant to the study because it is not seen in NA therapy. It was reported that high $\mathrm{HBs} \mathrm{Ag}$ level is a risk factor for carcinogenesis in inactive $\mathrm{HBV}$ carriers with negative $\mathrm{HBe} \mathrm{Ag}$ and low HBV-DNA level [19]. As most of the patients in the present study have shown similar condition with inactive low HBVDNA carrier by long-term entecavir therapy, the reduction effect of HBs Ag by adding PEG-IFN- $\alpha-2$ a on entecavir may lower carcinogenic risk. To confirm this, further study is needed.
Recent multicenter randomized trial of $180 \mu \mathrm{g}$ of PEGIFN- $\alpha$-2a with entecavir for patients with $\mathrm{HBe} \mathrm{Ag}$ positive chronic hepatitis B for 48 weeks showed that the rate of $\mathrm{HBe}$ Ag loss at 72 weeks was $32 \%$, which was higher than the $18 \%$ in entecavir monotherapy [20]. However, no $\mathrm{HBs} \mathrm{Ag}$ seroconversion was seen at 72 weeks even in add-on therapy. Although the number of $\mathrm{HBe} \mathrm{Ag}$ positive patients in the present study was small, the rate of $\mathrm{HBe}$ Ag loss by add-on therapy was $25 \%$, with no HBs Ag loss or seroconversion seen in $\mathrm{HBe} \mathrm{Ag}$ positive patients. Accordingly, it might be difficult that add-on PEG-IFN- $\alpha$-2a for HBe Ag positive patients treated with entecavir achieves $\mathrm{HBs} \mathrm{Ag}$ disappearance. In contrast, there are no reports of HBs Ag loss or seroconversion due to the addition of PEG-IFN- $\alpha$-2a to entecavir for $\mathrm{HBe} \mathrm{Ag}$ negative patients. In the present study, $\mathrm{CR}$ rate in $\mathrm{HBe}$ Ag negative patients was $27 \%$. Furthermore, in the case of patients with $\mathrm{HBe} \mathrm{Ag}$ negative and baseline HBs Ag level $<2000 \mathrm{IU} / \mathrm{mL}$, the CR rate rose to $50 \%$. Therefore, it is conceivable that optimal clinical indication of add-on PEG-IFN- $\alpha-2 \mathrm{a}$ therapy for patients treated with entecavir is considered as patients with $\mathrm{HBe} \mathrm{Ag}$ negative and low $\mathrm{HBs} \mathrm{Ag}$ level (at least $<2000 \mathrm{IU} / \mathrm{mL}$ ).

Baseline ALT level and the reduction of HBs Ag level were significant contributing factors for VR (more than 50\% reduction of baseline HBsAg level). Buster et al. reported that high levels of baseline ALT were among the predictive factors of viral response in PEG-IFN monotherapy, and genotypes $\mathrm{B}$ and $\mathrm{C}$ patients who had high levels of baseline ALT and low levels of HBV-DNA were good candidates for IFN monotherapy [21]. However, predicting VR using baseline ALT level was inferior compared with using the reduction of $\mathrm{HBs} \mathrm{Ag}$ level. At present, there is no established method for predicting treatment response of PEG-IFN using pretreatment factors except for genotype A [16]. Notably, some reports indicated 
TABLE 2: Comparison of pre- and on-treatment factors between the viral response and no viral response groups.

\begin{tabular}{|c|c|c|c|}
\hline Factors & $\operatorname{VR}(n=12)$ & No VR $(n=11)$ & $p$ \\
\hline Age (years) (range) & $52(36-62)$ & $44(30-65)$ & 0.211 \\
\hline Sex (male/female) & $10 / 2$ & $6 / 5$ & 0.193 \\
\hline Body weight (kg) & $65.9(53.0-91.0)$ & $56.6(45-110.5)$ & 0.104 \\
\hline BMI $\left(\mathrm{kg} / \mathrm{m}^{2}\right)$ & $23.9(17.9-30.1)$ & $21.2(17.9-32.3)$ & 0.151 \\
\hline Prior interferon therapy & 2 & 5 & 0.193 \\
\hline History of HCC treatment & 4 & 2 & 0.640 \\
\hline Genotype B/C & $1 / 11$ & $1 / 10$ & 1.000 \\
\hline Duration of prior entecavir (days) & $1831(560-2275)$ & $1316(371-2410)$ & 0.190 \\
\hline $\mathrm{HBe}$ Ag positive & 4 & 4 & 1.000 \\
\hline HBV-DNA $(\log \mathrm{IU} / \mathrm{mL})$ & $2.1(0-2.1)$ & $2.1(0-2.4)$ & 0.740 \\
\hline HBs Ag (IU/mL) & $1358(112-5807)$ & $1546(778-19674)$ & 0.651 \\
\hline Liver cirrhosis & 7 & 4 & 0.414 \\
\hline IL28B (rs8099917) major & 11 & 9 & 0.590 \\
\hline White blood cell $\left(/ \mathrm{mm}^{3}\right)$ & 4765 (3260-9100) & $5230(2920-6630)$ & 0.740 \\
\hline Hemoglobin $(\mathrm{g} / \mathrm{dL})$ & $14.9(14.0-15.8)$ & $14.6(12.0-16.5)$ & 0.379 \\
\hline Platelets $\left(\times 10^{4} / \mathrm{mm}^{3}\right)$ & $18.8(9.3-28.4)$ & $17.1(10.4-25.2)$ & 0.487 \\
\hline AST (IU/L) & $25(14-34)$ & $23(14-31)$ & 0.449 \\
\hline $\operatorname{ALT}(\mathrm{IU} / \mathrm{L})$ & $24(16-47)$ & $17(10-32)$ & 0.032 \\
\hline$\gamma \mathrm{GTP}(\mathrm{IU} / \mathrm{L})$ & $29(13-81)$ & $22(11-82)$ & 0.288 \\
\hline $\operatorname{AFP}(\mathrm{ng} / \mathrm{mL})$ & $2.2(1.0-6.9)$ & $2.7(1.2-4.6)$ & 0.651 \\
\hline Type IV collagen $7 \mathrm{~S}(\mathrm{ng} / \mathrm{mL})$ & $3.8(2.5-5.4)$ & $3.5(2.7-4.7)$ & 0.833 \\
\hline Hyaluronic acid (ng/mL) & $62(10-266)$ & $44(26-94)$ & 0.379 \\
\hline HBs $\mathrm{Ag}$ at week $4(\mathrm{IU} / \mathrm{mL})$ & $1434(101-5525)$ & 1637 (694-21699) & 0.651 \\
\hline Percentage reduction of $\mathrm{HBs} \mathrm{Ag}$ at week 4 & $6(-35-32)$ & $-1(-12-21)$ & 0.880 \\
\hline HBs Ag at week $8(\mathrm{IU} / \mathrm{mL})$ & $1159(118-4286)$ & $1544(608-19397)$ & 0.288 \\
\hline Percentage reduction of $\mathrm{HBs} \mathrm{Ag}$ at week 8 & $22(-5-51)$ & $1(-37-38)$ & 0.091 \\
\hline HBs Ag at week $12(\mathrm{IU} / \mathrm{mL})$ & $857(57-4391)$ & $1575(591-23678)$ & 0.134 \\
\hline Percentage reduction of $\mathrm{HBs} \mathrm{Ag}$ at week 12 & $35(-4-58)$ & $9(-29-41)$ & 0.004 \\
\hline HBs Ag at week $16(\mathrm{IU} / \mathrm{mL})$ & $966(2-3703)$ & $1329(570-27476)$ & 0.190 \\
\hline Percentage reduction of $\mathrm{HBs} \mathrm{Ag}$ at week 16 & $32(13-98)$ & $14(-40-36)$ & 0.007 \\
\hline
\end{tabular}

VR, viral response; HCC, hepatocellular carcinoma; HBe Ag, hepatitis B e antigen, HBs Ag, hepatitis B surface antigen; HBV, hepatitis B virus; IL, interleukin; ALT, alanine aminotransferase; $\gamma \mathrm{GTP}, \gamma$-glutamyltransferase.

Values are expressed as medians (range) or numbers of patients (percent).

TABLE 3: Areas under the curve according to significant contributing factors for viral response.

\begin{tabular}{llll}
\hline Factors & AUC & $p$ & $95 \%$ CI \\
\hline ALT & 0.761 & 0.034 & $0.561-0.961$ \\
Percentage reduction of HBs Ag at week 12 & 0.848 & 0.005 & $0.687-1.000$ \\
Percentage reduction of HBs Ag at week 16 & 0.833 & 0.007 & $0.687-1.000$ \\
\hline
\end{tabular}

AUC, area under the curve; CI, confidential interval; ALT, alanine aminotransferase; HBs Ag, hepatitis B antigen.

TABLE 4: Predictability of viral response.

\begin{tabular}{|c|c|c|c|c|c|}
\hline Factors & Sensitivity & Specificity & PPV & NPV & Accuracy \\
\hline ALT (>20 IU/L) & $67 \%(8 / 12)$ & $64 \%(7 / 11)$ & $67 \%(8 / 12)$ & $64 \%(7 / 11)$ & $65 \%(15 / 23)$ \\
\hline Reduction rate of HBs Ag at week $12(>25 \%)$ & $75 \%(9 / 12)$ & $82 \%(9 / 11)$ & $82 \%(9 / 11)$ & $75 \%(9 / 12)$ & $78 \%(18 / 23)$ \\
\hline Reduction rate of HBs Ag at week $16(>30 \%)$ & $75 \%(9 / 12)$ & $82 \%(9 / 11)$ & $82 \%(9 / 11)$ & $75 \%(9 / 12)$ & $78 \%(18 / 23)$ \\
\hline
\end{tabular}

PPV, positive predictive value; NPV, negative predictive value; ALT, alanine aminotransferase; HBs Ag, hepatitis B antigen. 
TABLE 5: Adverse events during treatment.

\begin{tabular}{lcc}
\hline & & Number \\
\hline Treatment discontinuation due to adverse event (total) & 1 \\
Arrhythmia & 1 & 4 \\
Treatment interruption due to adverse event (total) & 1 \\
Acute pyelonephritis & 1 \\
Acute pharyngitis & 1 \\
Thrombocytopenia & 1 \\
Vertigo & 10 \\
Other adverse events (total) & 4 \\
Dermatitis & 3 \\
Depression & 2 \\
Fever & 1 \\
Ischemic colitis & 1 \\
\hline
\end{tabular}

that $\mathrm{HBs} \mathrm{Ag}$ level or the reduction of $\mathrm{HBs} \mathrm{Ag}$ at week 12 was a strong predictor of virological response in pegIFN monotherapy [22-25]. It was also reported that titers of baseline $\mathrm{HBs} \mathrm{Ag}$ and $\mathrm{HB}$ core-related $\mathrm{Ag}$ were useful predictors of response to PEG-IFN $[26,27]$. In our study, there were no significant differences in baseline HBs Ag levels between VR and no VR groups. As the predictability of VR using the reduction of $\mathrm{HBs} \mathrm{Ag}$ level at week 12 was equal to that at week 16 , the optimal time point to predict VR would be 12 weeks after the start of therapy.

Certain limitations must be considered when interpreting the results of the present study. First, this represents a single-center, preliminary, small-scale, prospective cohort study without no control group. Although the effect of the reduction of HBs Ag by entecavir alone is small [28], it should be clear whether the reduction of $\mathrm{HBs} \mathrm{Ag}$ was due to the add-on PEG-IFN therapy or due to elongation of entecavir. Additionally, the number of the patients in our study is too small to draw a conclusion. A large scale randomized controlled trial is needed to validate our findings. Second, we defined VR as more than 50\% reduction of baseline HBs Ag level to evaluate the response of adding PEG-IFN, for convenience, and conclusion cannot be drawn as to whether this definition was appropriate. Because the range of $\mathrm{HBs}$ Ag levels in patients with $\mathrm{HBV}$ is very wide, and the meaning of a $50 \%$ reduction of $\mathrm{HBs} \mathrm{Ag}$ in clinical practice is unknown. Generally, efficacy of antiviral therapy for patients with chronic hepatitis B is evaluated by ALT or HBV-DNA levels. However, as ALT and HBV-DNA levels of the patients being treated with entecavir are very low, these markers are not available to evaluate outcomes of add-on PEG-IFN to NAs. It is reported that HBs Ag quantification is useful for monitoring natural history and treatment outcomes [29]. As $\mathrm{HBs}$ Ag seroclearance is required at the time of stopping NA as stated in international guidelines [30], CR should be defined as HBs Ag seroclearance in add-on PEG-IFN therapy to NAs. Third, this study is a report of Japanese patients mainly infected with genotype C HBV. As IFN has varying response, our results cannot be applied to other genotypes or races. Fourth, patients with previous lamivudine failure or breakthrough hepatitis during entecavir treatment were not included in the present study. Therefore, efficacy addon PEG-IFN therapy for mutant virus to NAs could not be evaluated.

In conclusion, adding PEG-IFN- $\alpha$-2a to entecavir is safe but has limited efficacy. The percentage reduction of $\mathrm{HBs} \mathrm{Ag}$ level at week 12 may be a useful predictor for VR. The best candidates by add-on PEG-IFN for the discontinuation of entecavir would be those who are $\mathrm{HBe} \mathrm{Ag}$ negative and with low HBsAg level (<2000 IU/mL).

\section{Conflicts of Interest}

The authors declare that there are no conflicts of interest regarding the publication of this paper.

\section{References}

[1] O. Yokosuka, K. Takaguchi, S. Fujioka et al., "Long-term use of entecavir in nucleoside-naïve Japanese patients with chronic hepatitis B infection," Journal of Hepatology, vol. 52, no. 6, pp. 791-799, 2010.

[2] A. S. F. Lok and B. J. McMahon, "Chronic hepatitis B: update 2009," Hepatology, vol. 50, no. 3, pp. 661-662, 2009.

[3] European Association for the Study of the Liver, "EASL Clinical Practice Guidelines: management of chronic hepatitis B," Journal of Hepatology, vol. 50, pp. 227-242, 2009.

[4] Y.-F. Liaw, N. Leung, J.-H. Kao et al., "Asian-Pacific consensus statement on the management of chronic hepatitis B: a 2008 update," Hepatology International, vol. 2, no. 3, pp. 263-283, 2008.

[5] Drafting Committee for Hepatitis Management Guidelines and the Japan Society of Hepatology, "JSH guidelines for the management of hepatitis B virus infection," Hepatology Research, vol. 44, supplement 1, pp. 1-58, 2014.

[6] L. Serfaty, D. Thabut, F. Zoulim et al., "Sequential treatment with lamivudine and interferon monotherapies in patients with chronic hepatitis B not responding to interferon alone: results of a pilot study," Hepatology, vol. 34, no. 3, pp. 573-577, 2001.

[7] X. Chen, Z. Cao, Y. Liu et al., "Potent hepatitis B surface antigen response to treatment of hepatitis-B-e-antigen-positive chronic hepatitis B with $\alpha$-interferon plus a nucleos(t)ide analog," 
Journal of Gastroenterology and Hepatology (Australia), vol. 27, no. 3, pp. 481-486, 2012.

[8] J. M. Kittner, M. F. Sprinzl, A. Grambihler et al., "Adding pegylated interferon to a current nucleos(t)ide therapy leads to HBsAg seroconversion in a subgroup of patients with chronic hepatitis B," Journal of Clinical Virology, vol. 54, no. 1, pp. 9395, 2012.

[9] E. Tanaka and A. Matsumoto, "Guidelines for avoiding risks resulting from discontinuation of nucleoside/nucleotide analogs in patients with chronic hepatitis B," Hepatology Research, vol. 44, no. 1, pp. 1-8, 2014.

[10] J. G. P. Reijnders, V. Rijckborst, M. J. Sonneveld et al., "Kinetics of hepatitis B surface antigen differ between treatment with peginterferon and entecavir," Journal of Hepatology, vol. 54, no. 3, pp. 449-454, 2011.

[11] Y. Tanaka, N. Nishida, M. Sugiyama et al., "Genome-wide association of IL28B with response to pegylated interferon- $\alpha$ and ribavirin therapy for chronic hepatitis C," Nature Genetics, vol. 41, no. 10, pp. 1105-1109, 2009.

[12] Y.-F. Liaw, J.-D. Jia, H. L. Y. Chan et al., "Shorter durations and lower doses of peginterferon alfa-2a are associated with inferior hepatitis B e antigen seroconversion rates in hepatitis B virus genotypes B or C," Hepatology, vol. 54, no. 5, pp. 1591-1599, 2011.

[13] P. Marcellin, G. K. K. Lau, F. Bonino et al., "Peginterferon Alfa-2a alone, lamivudine alone, and the two in combination in patients with HBeAg-negative chronic hepatitis B," New England Journal of Medicine, vol. 351, no. 12, pp. 1206-1217, 2004.

[14] G. K. K. Lau, T. Piratvisuth, X. L. Kang et al., "Peginterferon Alfa-2a, lamivudine, and the combination for HBeAg-positive chronic hepatitis B," New England Journal of Medicine, vol. 352, no. 26, pp. 2682-2695, 2005.

[15] Q. Xie, H. Zhou, X. Bai et al., "A randomized, open-label clinical study of combined pegylated interferon alfa-2a (40KD) and entecavir treatment for hepatitis B ' $\mathrm{e}$ ' antigen-positive chronic hepatitis B,' Clinical Infectious Diseases, vol. 59, no. 12, pp. 17141723, 2014.

[16] Editors of the Drafting Committee for Hepatitis Management Guidelines: The Japan Society of Hepatology, "Guidelines for the management of hepatitis C virus infection: first edition, May 2012, The Japan Society of Hepatology," Hepatology Research, vol. 43, no. 1, pp. 1-34, 2013.

[17] D. Ouzan, G. Pénaranda, H. Joly, H. Khiri, A. Pironti, and P. Halfon, "Add-on peg-interferon leads to loss of HBsAg in patients with $\mathrm{HBeAg-negative} \mathrm{chronic} \mathrm{hepatitis} \mathrm{and} \mathrm{HBV} \mathrm{DNA}$ fully suppressed by long-term nucleotide analogs," Journal of Clinical Virology, vol. 58, no. 4, pp. 713-717, 2013.

[18] P. Marcellin, S. H. Ahn, W. Chuang et al., "Predictors of response to tenofovir disoproxil fumarate plus peginterferon alfa-2a combination therapy for chronic hepatitis B," Alimentary Pharmacology \& Therapeutics, vol. 44, no. 9, pp. 957-966, 2016.

[19] T. Tseng, C. Liu, H. Yang et al., "High levels of hepatitis B surface antigen increase risk of hepatocellular carcinoma in patients with low HBV load," Gastroenterology, vol. 142, no. 5, pp. 1140.e3-1149.e3, 2012.

[20] W. P. Brouwer, Q. Xie, M. J. Sonneveld et al., "Adding pegylated interferon to entecavir for hepatitis $B$ e antigen-positive chronic hepatitis B: a multicenter randomized trial (ARES study)," Hepatology, vol. 61, no. 5, pp. 1512-1522, 2015.

[21] E. H. C. J. Buster, B. E. Hansen, G. K. K. Lau et al., "Factors that predict response of patients with hepatitis $\mathrm{B}$ e antigen-positive chronic hepatitis B to peginterferon-alfa," Gastroenterology, vol. 137, no. 6, pp. 2002-2009, 2009.
[22] R. Moucari, V. Mackiewicz, O. Lada et al., "Early serum HBsAg drop: a strong predictor of sustained virological response to pegylated interferon alfa-2a in HBeAg-negative patients," Hepatology, vol. 49, no. 4, pp. 1151-1157, 2009.

[23] V. Rijckborst, B. E. Hansen, Y. Cakaloglu et al., "Early ontreatment prediction of response to peginterferon alfa-2a for $\mathrm{HBeAg}$-negative chronic hepatitis $\mathrm{B}$ using $\mathrm{HBsAg}$ and $\mathrm{HBV}$ DNA levels," Hepatology, vol. 52, no. 2, pp. 454-461, 2010.

[24] M. J. Sonneveld, V. Rijckborst, C. A. B. Boucher, B. E. Hansen, and H. L. A. Janssen, "Prediction of sustained response to peginterferon alfa- $2 \mathrm{~b}$ for hepatitis $\mathrm{B}$ e antigen-positive chronic hepatitis B using on-treatment hepatitis B surface antigen decline," Hepatology, vol. 52, no. 4, pp. 1251-1257, 2010.

[25] C.-Y. Peng, H.-C. Lai, Y.-F. Li, W.-P. Su, P.-H. Chuang, and J.-T. Kao, "Early serum HBsAg level as a strong predictor of sustained response to peginterferon alfa-2a in $\mathrm{HBeAg}$ negative chronic hepatitis B," Alimentary Pharmacology and Therapeutics, vol. 35, no. 4, pp. 458-468, 2012.

[26] Y.-C. Wang, S.-S. Yang, C.-W. Su et al., "Predictors of response to pegylated interferon in chronic hepatitis B: a real-world hospital-based analysis," Scientific Reports, vol. 6, Article ID 29605, 2016.

[27] M. Martinot-Peignoux, M. Lapalus, S. Maylin et al., "Baseline $\mathrm{HBsAg}$ and $\mathrm{HBcrAg}$ titres allow peginterferon-based "precision medicine' in HBeAg-negative chronic hepatitis B patients," Journal of Viral Hepatitis, vol. 23, no. 11, pp. 905-911, 2016.

[28] Q. Ning, M. Han, Y. Sun et al., "Switching from entecavir to PegIFN alfa-2a in patients with HBeAg-positive chronic hepatitis B: a randomised open-label trial (OSST trial)," Journal of Hepatology, vol. 61, no. 4, pp. 777-784, 2014.

[29] M. Martinot-Peignoux, M. Lapalus, T. Asselah, and P. Marcellin, "HBsAg quantification: useful for monitoring natural history and treatment outcome," Liver International, vol. 34, supplement 1, pp. 97-107, 2014.

[30] W. Kang and J. Y. Park, "When to stop nucleos(t)ide analogues treatment for chronic hepatitis B? Durability of antiviral response," World Journal of Gastroenterology, vol. 20, no. 23, pp. 7207-7212, 2014. 


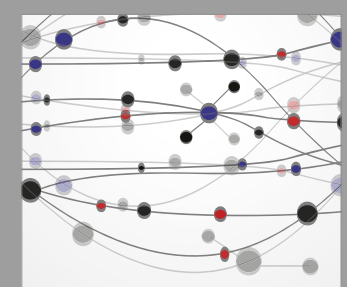

The Scientific World Journal
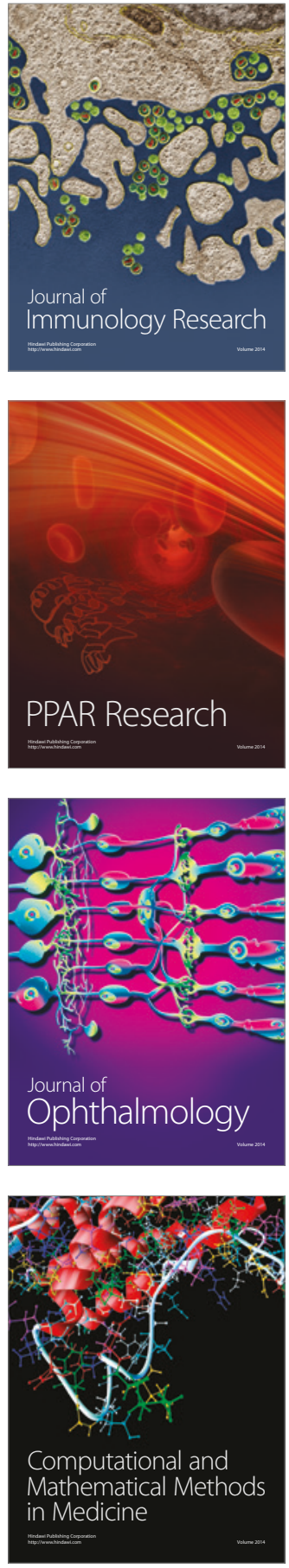

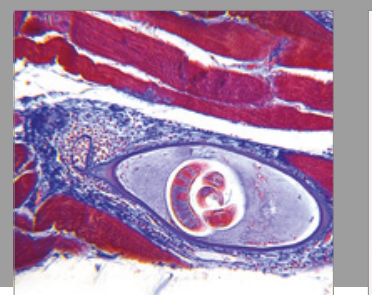

Gastroenterology Research and Practice
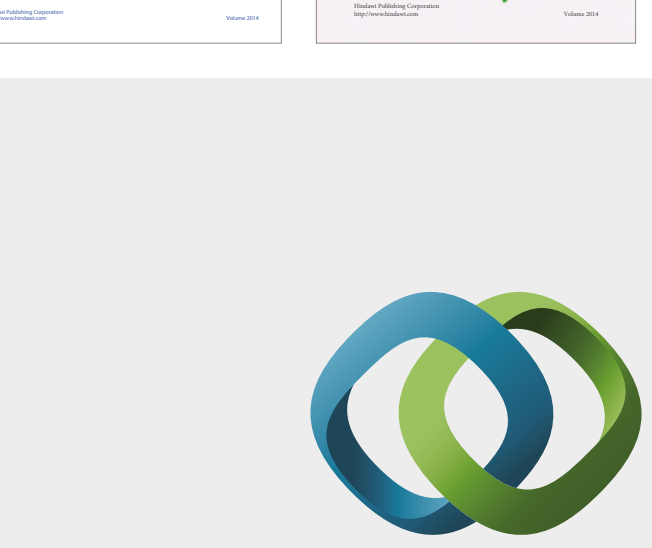

\section{Hindawi}

Submit your manuscripts at

https://www.hindawi.com
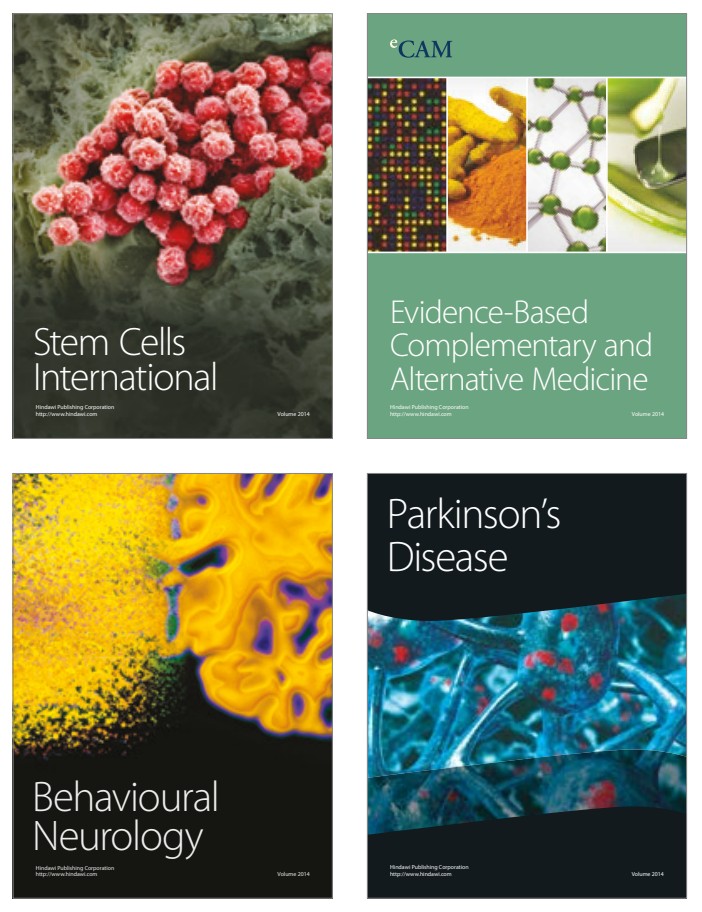
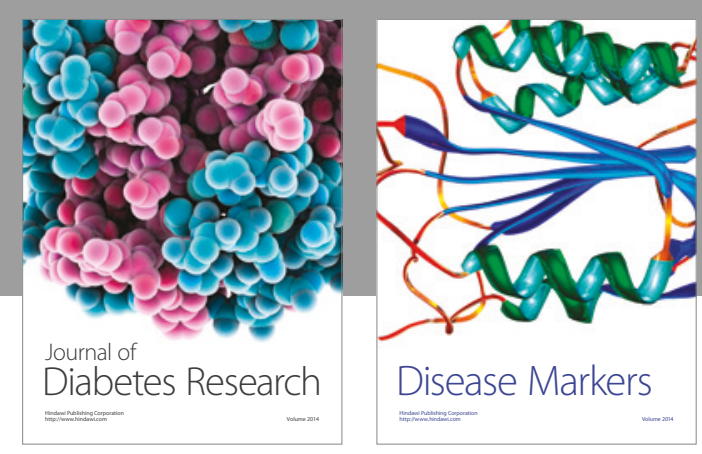

Disease Markers
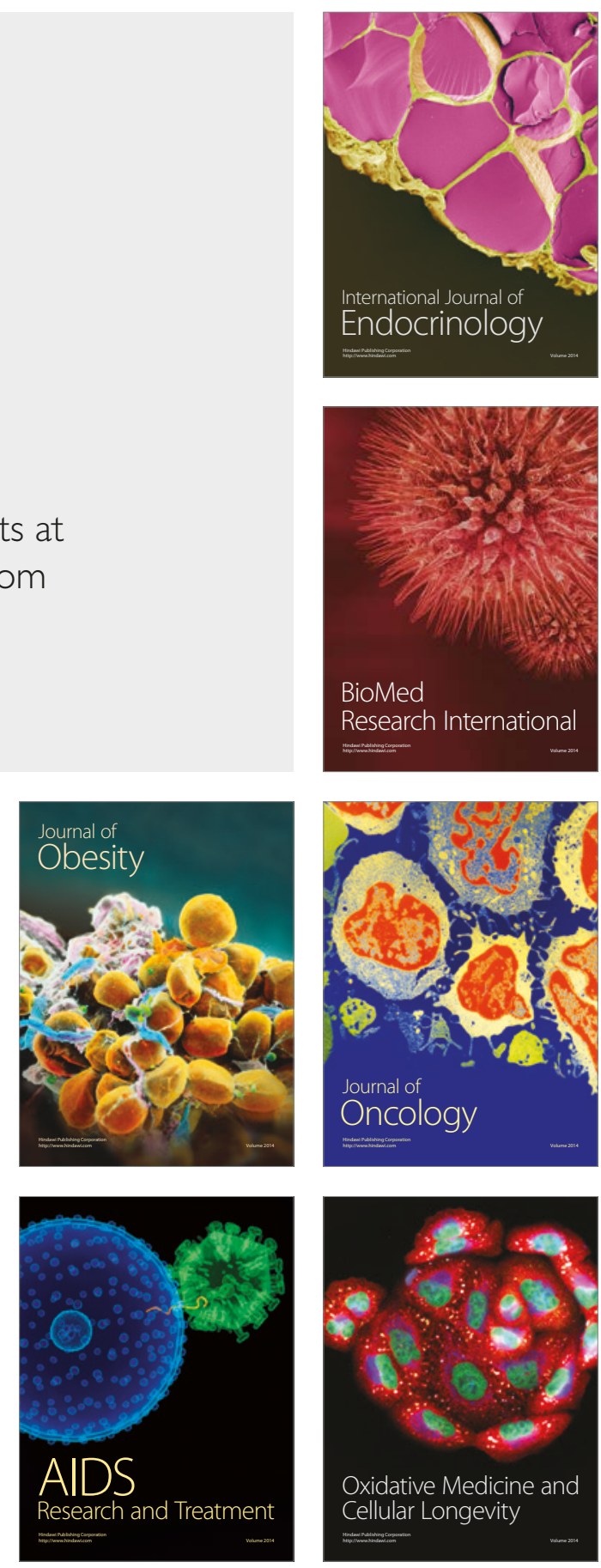